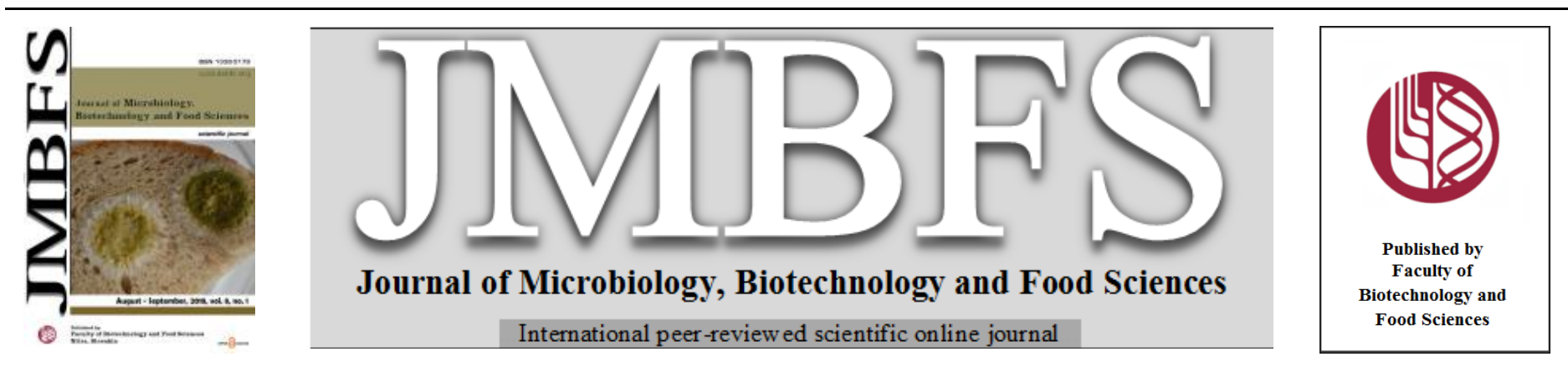

\title{
THE CONTENT OF POLYPHENOLS, ANTIOXIDANT ACTIVITY AND MACROELEMENTS IN SELECTED GARLIC VARIETIES
}

\section{Judita Bystrická*l , Ján Kovarovičl , Marianna Lenkovál , Jarmila Horváthová ${ }^{2}$, Lýdia Končeková $^{3}$, Daniela Halmová, Adriana Lidiková ${ }^{5}$}

Address(es): ${ }^{1}$ Slovak University of Agriculture in Nitra, Faculty of Biotechnology and Food Sciences, Department of Chemistry, Tr. A. Hlinku 2, 94976 Nitra, Slovakia.

${ }^{2}$ Slovak University of Agriculture in Nitra, Faculty of Economics and Management, Department of Languages, Tr. A. Hlinku 2, 94976 Nitra, Slovakia.

${ }^{3}$ Slovak University of Agriculture in Nitra, Faculty of European Studies and Regional Development, Department of Ecology, Tr. A. Hlinku 2, 94976 Nitra, Slovakia.

${ }^{4}$ Slovak University of Agriculture in Nitra, Faculty of European Studies and Regional Development, Department of Sustainable Development, Tr. A. Hlinku 2, 94976 Nitra, Slovakia.

${ }^{5}$ Slovak University of Agriculture in Nitra, Faculty of Horticulture and Landscape Engineering, Department of Vegetable Production, Tr. A. Hlinku 2, 94976 Nitra, Slovakia

*Corresponding author: judita.bystricka@centrum.sk

doi: 10.15414/jmbfs.2018.8.1.738-740

\section{ARTICLE INFO}

Received 29. 5. 2018

Revised 26. 6. 2018

Accepted 11. 7.2018

Published 1. 8. 2018

Regular article open $\mathcal{O}$ access

\begin{abstract}
This study provides some knowledge about content of total polyphenols, antioxidant activity and chosen macroelements in selected varieties of garlic (Allium sativum L.). Five garlic cultivars (Anton, Slavín, Gardos, Mirka and Flavor) were analyzed. The content of the total polyphenols (TPC) was determined by the Folin-Ciocalteu reagent (FCR) at $765 \mathrm{~nm}$ using spectrophotometer. Macroelements content was determined by the AAS method on Varian AA 240 FS. Antioxidant activity (AA) was measured using a compound DPPH (2.2-diphenyl-1-picrylhydrazyl). The content of (TPC) in fresh samples of garlic ranged from $401.25 \pm 8.54 \mathrm{mg} \cdot \mathrm{kg}^{-1} \mathrm{FM}_{\text {to }} 595.00 \pm 9.00$ mg. $\mathrm{kg}^{-1} \mathrm{FM}$ and the values of antioxidant activity in garlic samples were in range from $9.05 \pm 0.93 \%$ to $18.68 \pm 1.35 \%$. Statistically significant highest content TPC and AA was recorded in cultivar Slavín and the lowest in cultivar Flavor $(\mathrm{p}<0.05)$. Statistically significant highest content of magnesium, phosphorus, potassium was recorded in cultivar Anton and statistically significant highest content of sodium, calcium was recorded in cultivar Mirka. Statistically lowest content of magnesium, phosphorus, sodium, potassium, calcium was recorded in cultivar Flavor. The content of polyphenols, the antioxidant activity as well as the mineral content of garlic is influenced by the variety.
\end{abstract}

Keywords: garlic (Allium sativum L.), total polyphenols, antioxidant activity, macroelements

\section{INTRODUCTION}

Garlic (Allium sativum L.) is one of the best studied representatives of the Allium family. It has a unique position in history, have long been used to treat infections, colds, diabetes, heart disease and a range of other diseases. It contains many important components such as sulfur substances, vitamins, minerals, polyphenols, which positively influence human health. Garlic (Allium sativum L.) can be consumed in various forms: fresh, dried or heat treated. It is believed to originate in Central Asia, where it originated from a wildly growing species of Allium longicuspis (Iciek et al., 2012). Garlic was spread to the West, South and all of the world more than 6000 years ago. Egyptians used it to increase immunity and protect against various diseases, and to improve the performance of the pyramid builders (Sultan et al., 2014). The health properties of this natural plant depend on the contents of bioactive compounds, mainly polyphenolics and substances with antioxidant effects (Chun et al., 2005; Beato et al., 2011). Garlic is a rich source of phenolic substances. Polyphenols may be classified into different groups as a function of the number of phenol rings that they contain and on the basis of structural elements that bind these rings to each other. The main classes include phenolic acids, flavonoids, stilbenes and lignans (Spencer et al. 2008). Beato et al. (2011) mentions the presence of caffeic acid, ferulic acid, vanillic acid, $p$-hydroxybenzoic acid, and $p$-coumaric acid in garlic. Contents of biologically-active compounds in garlic vary between cultivars grown in different geographical regions (Beato et al., 2011). A number of health benefits of garlic depend on its antioxidant activity (Szychowski et al., 2018). Two important compounds of garlic, $S$-allylcysteine and $S$-allylmercapto- $L$-cysteine have the highest antioxidant activity. For these compounds, garlic consumption can be considered as a preventive form of protection against cancer (Thomson et al., 2003). Garlic is a source of minerals as potassium, iron, zinc, calcium, sulphur, magnesium, manganese and selenium. Mineral profile of garlic was also dealt with by Akinwande and Olatunde (2015) who report high potassium, phosphorus, calcium, magnesium and zinc. Selenium is a mineral that is essential to a healthy heart and is also an important cofactor of antioxidant enzymes in the body. (Hegedúsová et al., 2017). Manganese acts in the body as a cofactor for the antioxidant enzyme superoxide dismutase. Iron is essential for the formation of red blood cells (Kik et al., 2001). The objectives of this work were to compare and evaluate content of polyphenols, antioxidant activity and macroelements in selected varieties of garlic.

\section{MATERIAL AND METHODS}

The experiment was established in the area of Nitra (demonstration garden SAU) block methods (cultivars of garlic was planted by hand to 4 lines, size of the experimental plot $1 \mathrm{~m}^{2}$ ). Autumn varieties (Anton, Slavín, Gardos) were planted in the second half of November and the spring varieties (Mirka, Flavor) were established in the first half of March. This area is situated on the southern Slovakia. Nitra belongs to warmer areas in Slovakia. The average annual rainfall is $550-600 \mathrm{~mm}$ and the average annual temperature is $9.9^{\circ} \mathrm{C}$.

\section{Samples of plant material}

The samples of plant material (cultivars of garlic Anton, Slavín, Gardos, Mirka, Flavor) were collected in the phase of full ripeness from area of Nitra. All samples of plant material were grown under the same conditions. Only NPK fertilization (200 g.m $\left.\mathrm{m}^{-2}\right)$ was used for the achievement of favourable soil macroelements content. Agrochemical characteristic of soil in that region shown in the Tab 1. 
Table 1 Agrochemical characteristic of soil substrate in $\mathrm{mg} \cdot \mathrm{kg}^{-1}$

\begin{tabular}{|c|c|c|c|c|c|c|c|c|c|}
\hline \multirow{2}{*}{$\begin{array}{l}\text { Agrochemical } \\
\text { characteristic }\end{array}$} & $\begin{array}{c}\mathbf{p H} \\
\left(\mathbf{H}_{2} \mathbf{O}\right)\end{array}$ & $\begin{array}{c}\mathrm{pH} \\
(\mathrm{KCl})\end{array}$ & $\begin{array}{l}\text { Cox } \\
(\%) \\
\end{array}$ & $\begin{array}{c}\text { Humus } \\
(\%)\end{array}$ & & & & & \\
\hline & 8.23 & 7.06 & 1.72 & 2.97 & & & & & \\
\hline \multirow{2}{*}{ Nutrients } & $\mathbf{N}_{\text {inorganic }}$ & $\mathbf{K}$ & $\mathbf{C a}$ & Mg & $\mathbf{P}$ & & & & \\
\hline & 36 & 214 & 6,810 & 568 & 95 & & & & \\
\hline Heavy metals & $\mathbf{Z n}$ & $\mathrm{Cu}$ & Mn & $\mathrm{Fe}$ & $\mathrm{Cr}$ & Cd & $\mathbf{P b}$ & Co & $\mathbf{N i}$ \\
\hline Aqua regia & 91.3 & 23.7 & 646.90 & 25,965 & 34.9 & 0.84 & 39.60 & 13.20 & 42.2 \\
\hline Limit value* & 100.0 & 60.0 & - & - & 70.0 & 0.4 & 70.0 & 15.0 & 40.0 \\
\hline $\begin{array}{c}\mathrm{NH}_{4} \mathrm{NO}_{3} \\
\left.\text { (c = } 1 \text { mol.dm }{ }^{-3}\right)\end{array}$ & 0.05 & 0.10 & 0.36 & 0.11 & 0.05 & 0.171 & 0.51 & 0.20 & 0.29 \\
\hline Critical value ${ }^{* *}$ & 2.0 & 1.0 & - & - & - & 0.1 & 0.1 & - & 1.5 \\
\hline
\end{tabular}

Legend: *Limit value for Aqua regia- Law no. 220/2004

** Critical value for $\mathrm{NH}_{4} \mathrm{NO}_{3}\left(\mathrm{c}=1\right.$ mol.dm $\left.{ }^{-3}\right)$ - Law no. $220 / 2004$

\section{Preparations of samples}

Extract was prepared from the $25 \mathrm{~g}$ samples of different varieties of garlic, which were crushed and shaken (shaker GFL 3006, $125 \mathrm{rpm}$ ) in $50 \mathrm{ml}$ of $80 \%$ ethano for sixteen hours. Samples were kept at laboratory room temperature in dark conditions until the analysis. Each determination was carried out in four replications.

\section{Determination of total polyphenols (TPC)}

Total polyphenols content (TPC) was determined according to Lachman $\boldsymbol{e t}$ al (2003). It is expressed as $\mathrm{mg}$ of gallic acid equivalent per $\mathrm{kg}$ of fresh matter. Total polyphenols content was determined using $2.5 \mathrm{ml}$ of Folin-Ciocalteu reagent which was added to $100 \mu \mathrm{l}$ extract to volumetric flask. The content was mixed. After 3 minutes, $5 \mathrm{ml} 20 \%$ solution of sodium carbonate was added. Then the volume was adjusted to $50 \mathrm{ml}$ with distilled water. After 2 hours, the samples were centrifuged (UNIVERSAL 320, $15000 \mathrm{rpm}$ ) for 10 minutes. The absorbance was measured of the spectrophotometer (Shimadzu UV/VIS) at 765 $\mathrm{nm}$. The concentration of polyphenols was calculated from a standard curve with known concentration of gallic acid. Results were expressed as mg gallic acid equivalents (GAE) per kg fresh weight $(\mathrm{FW})$.

\section{Determination of antioxidant activity (AA)}

Antioxidant activity was measured by the Brand-Williams et al. method (1995), using a compound DPPH' (2.2-diphenyl-1-picrylhydrazyl) (Merck). DPPH was pipetted into cuvettes $(3.9 \mathrm{ml})$, then was written the value of absorbance, which corresponded to the initial concentration of $\mathrm{DPPH}^{-}$solution in time Ao. Then 0.1 $\mathrm{cm}^{3}$ of the followed solution was added and then was immediately started to measure the dependence $A=f(t)$. The solution in the cuvettes were mixed and measured the absorbance of 1,5 and 10 minutes (At) at $515.6 \mathrm{~nm}$ in the spectrophotometer Shimadzu UV/VIS-1240. The percentage of inhibition reflects the ability of the sample to remove $\mathrm{DPPH}^{*}$ radical at the given time $(\mathrm{A} 0-\mathrm{At})$.

$$
\text { Inhibition }(\%)=(\text { Ao }- \text { At } / \text { Ao }) \times 100
$$

\section{Chemical analysis of macroelements in plant material}

Homogenized garlic samples were mineralized in a closed system of microwave digestion using Mars X-Press 5 (CEM Corp., USA) in a mixture of $5 \mathrm{ml} \mathrm{HNO}_{3}$ (Suprapur, Merck, Germany) and $5 \mathrm{ml}$ of perchloric acid. After the sample was filtred into $100 \mathrm{ml}$ volumetric flask through filter paper. The filter paper was washed with hot distilled water along. Before determining the $\mathrm{K}, \mathrm{Na}, \mathrm{Mg}$, and $\mathrm{Ca}$ contents, the treated sample was diluted with distilled water. Also blank sample was prepared. The content of macrobiogenic elements was determined by the AAS method on Varian AA 240 FS. P content was determined on a Shimadzu spectrophotometer at a wavelength of $666 \mathrm{~nm}$. The mineral content of garlic has been calculated using a dry matter percentage to dry weight.

\section{Statistical analysis}

Results were statistically evaluated by the Analysis of Variance (ANOVA Multiple Range Tests, Method: 95.0 percent LSD). It was used by the statistical software STATGRAPHICS (Centurion XVI.I, USA).

\section{RESULTS AND DISCUSSION}

Garlic (Allium sativum L.) is one of the most commonly produced vegetables worldwide. It has potential health-promoting effects due to its high phenolic phytochemical content and it is a source of natural antioxidants (Nuutila $\boldsymbol{e t}$ al. 2003). Tab 2 shows the range of total polyphenol content and antioxidant activity in the studied garlic varieties. Average content of total polyphenols and antioxidant activity in selected cultivars of garlic shown in the Tab 2.

Table 2 Average content of total polyphenols and antioxidant activity in selected cultivars of garlic

\begin{tabular}{lcc}
\hline Cultivars & TPC $\left(\mathbf{m g . k \mathbf { k g } ^ { - 1 }} \mathbf{F M}\right)$ & AA $(\%$ inhibition $)$ \\
\hline Anton & $539.32 \pm 10.57^{\mathrm{d}}$ & $15.61 \pm 1.14^{\mathrm{c}}$ \\
Slavín & $595.00 \pm 9.00^{\mathrm{e}}$ & $18.68 \pm 1.35^{\mathrm{d}}$ \\
Gardos & $485.05 \pm 10.60^{\mathrm{b}}$ & $12.98 \pm 0.91^{\mathrm{b}}$ \\
Mirka & $506.60 \pm 10.38^{\mathrm{c}}$ & $16.13 \pm 1.15^{\mathrm{c}}$ \\
Flavor & $401.25 \pm 8.54^{\mathrm{a}}$ & $9.05 \pm 0.93^{\mathrm{a}}$ \\
\hline
\end{tabular}

Legend: Multiple Range Tests, Method: 95.0 percent LSD, Different letters (a - e) between the factors show statistically significant differences $(\mathrm{p}<0.05)-$ LSD test.

The total content of polyphenols in the samples ranges from $401.30 \pm 8.54$ to $595.0 \pm 9.00 \mathrm{mg} \cdot \mathrm{kg}^{-1}$. Our results are in correspondence with the results of Jastrzebski et al. (2007), who indicated content of polyphenols in an amount 493 mg. $\mathrm{kg}^{-1}$. Similarly Chekki et al. (2014) recorded that TPC in garlic is $410 \mathrm{mg} . \mathrm{kg}$ 1. Some authors also report a higher TPC value in garlic: $812 \mathrm{mg} \cdot \mathrm{kg}^{-1}$ (Charles, 2013), 780 mg. $\mathrm{kg}^{-1}$ (Batcioglu et al. 2012). In this study, we evaluated the value of antioxidant activity in selected cultivars of garlic. Our values were in interval from $9.05 \pm 0.93 \%$ to $18.68 \pm 1.35$ (Tab 2). Based on the measured values of antioxidant activity in garlic, cultivars can be classified as follows: Slavín (18.68 $\%)>\operatorname{Mirka}(16.13 \%)>$ Anton $(15.61 \%)>$ Gardos $(12.98 \%)>$ Flavor $(9.05$ $\%)$. Chen et al. (2013) indicated in his study in wide range the values of antioxidant activity, in comparison with our results. Their values were in interval from 3.60 to $45.63 \%$. But Choi et al. (2014) report a lower value of antioxidant activity in garlic $(4.65 \%)$.

Another significant parameter, that was monitored in this study, was the content of macroelements in selected varieties of garlic. Average macroelements in selected cultivars of garlic shown in the Tab 3.

$\underline{\text { Table } 3 \text { Average macroelements in selected cultivars of garlic }\left(\mathrm{mg}_{\mathrm{kg}} \mathrm{kg}^{-1} \mathrm{DM}\right)}$

\begin{tabular}{lcccccc} 
Cultivars & $\mathbf{M g}$ & $\mathbf{P}$ & $\mathbf{N a}$ & $\mathbf{K}$ & $\mathbf{C a}$ & $\mathbf{N a} / \mathbf{K}$ \\
\hline Anton & $388.60^{\mathrm{d}}$ & $5152^{\mathrm{e}}$ & $87.98^{\mathrm{c}}$ & $15143^{\mathrm{e}}$ & $149.74^{\mathrm{b}}$ & 0.0058 \\
Slavín & $361.17^{\mathrm{c}}$ & $5041^{\mathrm{d}}$ & $62.52^{\mathrm{b}}$ & $8840^{\mathrm{c}}$ & $253.72^{\mathrm{c}}$ & 0.00704 \\
Gardos & $354.85^{\mathrm{c}}$ & $3460^{\mathrm{b}}$ & $83.94^{\mathrm{c}}$ & $13721^{\mathrm{d}}$ & $252.58^{\mathrm{c}}$ & 0.00611 \\
Mirka & $331.21^{\mathrm{b}}$ & $3667^{\mathrm{c}}$ & $92.42^{\mathrm{d}}$ & $8697^{\mathrm{b}}$ & $317.35^{\mathrm{d}}$ & 0.0106 \\
Flavor & $223.59^{\mathrm{a}}$ & $3353^{\mathrm{a}}$ & $57.26^{\mathrm{a}}$ & $8452^{\mathrm{a}}$ & $136.66^{\mathrm{a}}$ & 0.00677
\end{tabular}

Legend: Multiple Range Tests, Method: 95.0 percent LSD, Different letters (a - e) between the factors show statistically significant differences $(\mathrm{p}<0.05)-$ LSD test.

There is little information in the literature about the macroelements content in garlic. The level of macroelements found in the studied varieties of garlic was very different. The significantly highest content of calcium was determined in variety "Mirka" (317.35 mg.kg ${ }^{-1}$ ) compared to other examined varieties ( $\mathrm{p}<$ $0.05)$. The significantly lowest content of calcium was determined in variety "Flavor" (136.66 mg.kg-1) compared to other examined varieties $(\mathrm{p}<0.05)$ Haciseferogullari et al. (2005) reported higher content of calcium (360 mg.kg-1) Otunola et al. (2010) indicated content of calcium in garlic in the amount 263 $\mathrm{mg} \cdot \mathrm{kg}^{-1}$. Content of potassium values in our study were in the range $8452-15143$ mg. $\mathrm{kg}^{-1}$. Our results were in coherence wit findings of Akinwane and Olatunde (2015), who indicated the amount of potassium in interval from $14291 \mathrm{mg} \cdot \mathrm{kg}^{-1}$ to 
$17298 \mathrm{mg} \cdot \mathrm{kg}^{-1}$. Potassium is very important macroelements that plays a role in electrolyte balance in the human body and in nerve impulse transmission (Ștef $\boldsymbol{e}$ al., 2010). Quantity of magnesium, phosphorus, and sodium has values that ranged between 223.59 - $388.60 \mathrm{mg} \cdot \mathrm{kg}^{-1}, 3353$ - $5152 \mathrm{mg} \cdot \mathrm{kg}^{-1}$, and $57.26-$ $92.42 \mathrm{mg} \cdot \mathrm{kg}^{-1}$, respectively. Akinwane and Olatunde (2015) determined a higher content of magnesium in garlic, in comparison with our results. Their values were $710 \mathrm{mg} \cdot \mathrm{kg}^{-1}$. Tegegne et al. (2016) indicated the levels of magnesium in the interval from $802 \mathrm{mg} \cdot \mathrm{kg}^{-1}$ to $992.6 \mathrm{mg} \cdot \mathrm{kg}^{-1}$. These values are also higher than the values determined by us. Magnesium present in many enzymes involved in proteins, lipids and carbohydrates metabolism (Stef $\boldsymbol{e t}$ al. 2010). Sodium is necessary for humans to maintain the balance of the physical fluids system, is also required for nerve and muscle functioning (Munteau and Iliuțã 2011). The Na:K ratio is significant for blood pressure (Yusuf et al., 2007) and recommended to be less than one. The significantly highest content of sodium was determined in variety "Mirka" (92.42 mg.kg $\left.{ }^{-1}\right)$ and the significantly lowest content of sodium was determined in variety "Flavour" $\left(57.26 \mathrm{mg} \cdot \mathrm{kg}^{-1}\right)$. Tegegne et al. (2016) indicated the amount of sodium in interval from 217 mg.kg ${ }^{-1}$ to $367 \mathrm{mg} \cdot \mathrm{kg}^{-1}$. The last monitored element in garlic was phosphorus. The values that we found were in good accordance with Akinwane and Olatunde (2015), who indicated similar values of phosphorus (4777 mg. $\left.\mathrm{kg}^{-1}\right)$ in garlic. Phosphorus is the second most abundant essential mineral in the human body after calcium. Plays a role in numerous biologic processes, including energy metabolism and bone mineralization (Raina et al., 2012). Macroelements are very important for the human organism. Acceptance of mineral elements from varied diet is the most natural and best way to achieve optimal amount the body. Mineral elements contained in garlic are a valuable source in the human diet. The $\mathrm{Na}$ K ratio, significant for blood pressure and recommended to be less than one (Yusuf et al., 2007). In all studied varieties of garlic, we measured lower values than this value, which means, that garlic can be used in a dietary regime to lower blood pressure.The epidemiological studies indicate, that in areas where garlic is consumed regularly, the incidence of cardiovascular diseases are lower (Durak $\boldsymbol{e}$ al., 2004; Bat-Chen et al., 2010). The content of macroelements in plants is affected by the plant species and cultivar, but also by fertilization (Markiewicz and Golcz, 2010), but also by fertilization (Markiewicz and Golez, 2010), including S-fertilization, because of yield and its quality (lower nitrates content in tissues and higher content of positive secondary S-metabolites) ( Losak and Kielian, 2006).

\section{CONCLUSION}

The bioactive components of garlic are mainly responsible for the healing properties. It was shown that the content of polyphenols and antioxidant activity of garlic is variety-dependent. The highest content of polyphenols as well as antioxidant activity was determined in breeding cultivar Slavín. Similar variation among studied varieties regarding macroelements content was observed. Statistically significant highest content of magnesium, phosphorus, potassium was recorded in cultivar Anton and statistically significant highest content of sodium, calcium was recorded in cultivar Mirka. Statistically lowest content of magnesium, phosphorus, sodium, potassium, calcium was recorded in cultivar Flavor.

Acknowledgments: This work was supported by scientific grant VEGA 1/0139/17, VEGA 1/0114/18, KEGA 011SPU-4/2017.

\section{REFERENCES}

AKINWANDE, B.A., OLATUNDE, S.J. 2015. Comparative evaluation of the mineral profile and other selected components of onion and garlic. International Food Research Journal, 22(1), 332-336. ISSN 19854668.

BAT-CHEN W., GOLAN T., PERI I., LUDMER Z., SCHWARTZ B. 2010. Allicin purified from fresh garlic cloves induces apoptosis in colon cancer cells via Nrf2. Nutr. Cancer, 62(7), 947-57. http://dx.doi.org/10.1080/01635581.2010.509837.

BATCIOGLU, K., YILMAZ, Z., SATILMIS, B., UYUMLU, A. B., ERKAL, H. S. YUCEL, N., GUNALS, S., SERIN, M., DEMIRTAS, H. 2012. Investigation of in vivo radioprotective and in vitro antioxidant and antimicrobial activity of garlic (Allium sativum). European Review for Medical and Pharmacological Sciences, 16(3), 47-57. PMid:22957418.

BEATO, V. M., ORGAY, F., MANSILlA, F., MONTANO, A. 2011. Changes in phenolic compounds in garlic (Allium sativum L.) owing to the cultivar and location of growth. Plant Foods Him. Nutr., 66(3), 218-223. http://dx.doi.org/10.1007/s11130011-0236-2

CHARLES, D. J. 2013. Antioxidant Properties of Spices, Herbs and Other Sources. NY: Springer science. http://dx.doi.org/10.1007/978-1-4614-4310-0

CHEKKI, R. Z., SNOUSSI, A., HAMROUNI, I., BOUZOUITA, N. 2014. Chemical composition, antibacterial and antioxidant activities of Tunisian garlic (Allium sativum) essential oil and ethanol extract. Mediterranean Journal of Chemistry, 3(4), 947-956. http://dx.doi.org/10.13171/mjc.3.4.2014.09.07.11

CHEN, S., SHEN, X., CHENG, S., LI, P., DU, J. 2013. Evaluation of garlic cultivar for polyphenolic content and antioxidant properties. Plos One, 8(11), e79730. http://dx.doi.org/10.1371/journal.pone.0079730
CHOI, S., CHA, H. S., LEE, Y. S. 2014. Physicochemical and Antioxidant Properties of Black Garlic. Molecules, 19(10), 16811-16823. http://dx.doi.org/10.3390/molecules191016811

CHUN, O. K., KIM, D. O., SMITH, N., SCHROEDER, D., HAN, J. T., LEE, C. Y 2005. Daily consumption of pheolics and total antioxidant capacity from fruit and vegetables in the American diet. Journal of the Science of Food and Agricultural, 85(10), 1715-1724. http://dx.doi.org/10.1002/jsfa.2176

DURAK I., KAVUTCU M., AYTA B. 2004. Effects of garlic extract consumption on blood lipid and oxidant/ antioxidant parameters in humans with high blood cholesterol. J. Nutr. Bioch., 15(6), 373-377. http://dx.doi.org/10.1016/i.jnutbio.2004.01.005 HACISEFEROGULLARI H., ÖZCAN M., DEMIR F., CALISIR, S. 2005. Some nutritional and technological properties of garlic (Allium sativum L.). J. Food Eng., 68(4), 463-469. https://doi.org/10.1016/i.jfoodeng.2004.06.024

HEGEDÜSOVÁ, A., MEZEYOVÁ, I., HEGEDÜS, O., ANDREJIOVÁ, A. JURÍKOVÁ, T., GOLIAN, M., LOŠÁK, T. 2017. Increasing of selenium content and qualitative parameters in garden pea (Pisum sativum L.) after its folia application. Acta Scientiarum Polonorum. Hortorum Cultus, 16(6), 3-17. http://dx.doi.org/10.24326/asphc.2017.6.1

ICIEK, M., KWIECIEN, I., CHWATKO, G., JEZEWICZ, M. S., PACHEL, D. K.,

ROKITA, H. 2012. The effect of garlic-derived sulphur compounds on cell

proliferation, caspase 3 activity, thiol levels ad anaerobic sulphur metabolism in human hepatoblastoma. Cell Biochemistry and Function, 30(3), 198-204.

https://doi.org/10.1002/cbf.1835

JASTRZEBSKI, Z., LEONTOWICZ, H., LEONTOWICZ, M., NAMIESNIK, J., ZACHWIEJA, Z., BARTON, H., PAWELZIK, E., ARANCIBIA-AVILA, P., TOLEDO, F., GORINSTEIN, S. 2007 The bioactivity of processed garlic (Allium sativum L.) as shown in vitro and in vivo studies on rats. Food and Chemical Toxicology, 45(9), 1626-1633. https://doi.org/10.1016/j.fct.2007.02.028

KIK, C., KAHANE, R., GEBHARDT., R., 2001. Garlic and health. Nutrition and Metabolic Cardiovascular Diseases, 11(4), 2001, 57-65. PMid: 11894756.

LOSAK, T., WISNIOWSKA-KIELIAN, B. 2006. Fertilization of garlic (Allium sativum L.) with nitrogen and sulphur. Annales Universitatis Mariae CurieSklodowska. Sectio E Agricultura (Poland), 61, 45-50. ISSN: 0365-1118.

MARKIEWICZ, B., GOLCZ, A. 2010. Effect of nitrogen, phosphorus and potassium fertilization on yielding and biological value of fruits of aubergine (Solanum

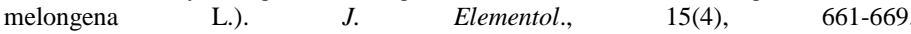
http://dx.doi.org/10.5601/jelem.2011.16.1.69-74

MUNTEANU, C., ILIUTÃ A. 2011. The role of sodium in the body. Balneo-Research Journal, 2(1), 70-74. https://doi.org/10.12680/balneo.2011.1015

NUUTILA, A.M., PUUPPONEN-PIMIA, R., AARNI, M., OKSMAN-CALDENTEY, K. 2003. Comparison of antioxidant activities of onion and garlic extracts by inhibition of lipid peroxidation and radical scavenging activity. Food Chem, 81(4), 485-493. https://doi.org/10.1016/S0308-8146(02)00476-4

OTUNOLA, G.A., OLOYEDE, O.B., OLADIJI, A.T., AFOLAYAN, A.J. 2010 Comparative analysis of the chemical composition of three spices - Allium sativum L. Zingiber officinale Rosc. And Capsicum frutescens L. commonly consumed in Nigeria. African Journal of Biotechnology, 9(41), 6927-6931. http://dx.doi.org/10.5897/AJB10.183

RAINA, R., GARG, G., SETHI, S. K., SCHREIBER, M.J., SIMON, J.F., THOMAS, G. 2012. Phosphorus metabolism. Journal of Nephrology \& Therapeutics, S3:008 https://doi.org/10.4172/2161-0959.s3-008

SPENCER, J. P., ABD EL MOHSEN, M. M., MINIHANE, A. M., MATHERS, J. C. 2008. Biomarkers of the intake of dietary polyphenols: strengths, limitations and application in nutrition research. British Journal of Nutrition, 99(1), 12-22. http://dx.doi.org/10.1017/S0007114507798938

ŞTEF, D.S., GERGEN, I., ŞTEF, L., HĂRMĂNESCU, M., POP, C., DRUGĂ, M., BUJANCĂ, G., POPA, M. 2010. Determination of the macro elements content of some medicinal herbs. Scientific Papers Animal Science and Biotechnologies 43(1), 122-126. ISSN: 2344-4576.

SULTAN, M. T., BUTT, M. S., QAYYUM, M. M., SULERIA, H. A. 2014. Imunnity: plants as effective mediators. Critical Reviews in Food Science and Nutrition, 54(10), 1298-1308. https://doi.org/10.1080/10408398.2011.633249

SZYCHOWSKI, K.A., RYBCZYŃSKA-TKACZYK, K., GAWEL-BEBEN, K., ŚWIECA, M., KARAŚ, M., JAKUBCYZK, A., MATZSIAK, M., BINDUGA, U.E., GMIŃSKI, J. 2018. Characterization of active compounds of different garlic (Allium sativum L.) cultivars. Pol. J. Food Nutr. Sci., 68(1), 73-81. https://doi.org/10.1515/pjfns-2017-0005

TEGEGNE, W.A., MENGISTE, A.A. 2016. Determination of essential and nonessential metals concentration in garlic (Allim sativum L.) bulb and leaf cultivated in Ambo Woreda, Ethiopia. Science Journal of Analytical Chemistry, 4(6), 84-94. https://doi.org/10.11648/j.sjac.20160406.12

THOMSON, M., ALI, M., 2003. Garlic (Allium sativum): A Review of its Potentia Use as an Anti-Cancer. Curret Cancer Drug Targets, 3 (1), 67-81. http://dx.doi.org/10.2174/1568009033333736

YUSUF, A. A., MOFIO, B. M., AHMED, A. B. 2007. Proximate and mineral composition of Tamarindus indica Linn. 1753 seeds. The Scientific World Journal, 2(1), 1-4. http://dx.doi.org/10.4314/swj.v2i1.51699 